\title{
NOCTURNAL SLEEP PATTERN IN NATIVE BRAZILIAN TERENA ADULTS
}

\author{
RUBENS REIMÃO*, JOSÉCARLOS SOUZA**, CARLOSEDUARDO VILELA GAUDIOSO***, \\ HELLEN DA COSTA GUERRA ***, ANDREA DAS CHAGASALVES ${ }^{* * *}$ \\ JOLENE CRISTINA FERREIRA OLIVEIRA***, NILTON CEZAR ANTONIO GNOBIE****, \\ DESIRÉE CORREA GUERRA SILVERIO****
}

\begin{abstract}
Social-economic factors influence sleep habits. This research analyzes characteristics of nocturnal sleep in Brazilian Native Terena adults. Sixty-four adults (31 M; 33 F) from 18 to 75 years, with a mean age of 37.0, from the Indian Reservation village of Córrego do Meio, in the central region of Mato Grosso do Sul, an agriculturally oriented group were evaluated. Nocturnal sleep characteristics were evaluated by means of a standard questionnaire applied to each individual. It was observed that reported nocturnal sleep was longer, sleep onset was earlier and wake up time was also earlier than usually described in urban populations. The mean total time in bed was $8.5 \mathrm{~h}$ or more, in every age bracket. The seven-day prevalence rate of insomnia was $4.6 \%$, while the seven-day prevalence rate of hypnotic use was $1.5 \%$, both remarkably less than described in urban populations. These findings stress the need to consider ethnic influences on sleep patterns and disorders.
\end{abstract}

KEY WORDS: sleep, sleep habits, insomnia, sleep disorder, hypnotic, Native, Indian, Terena, Mato Grosso do Sul, ethnic.

\section{Padrão de sono noturno em adultos indígenas Terena}

RESUMO - Fatores sócio-econômicos influenciam os hábitos de dormir. A presente pesquisa analisa as características do sono noturno em indígenas Terena. Avaliamos 64 adultos (31 M; 33 F) de 18 a 75 anos de idade (média 37,0 anos) da aldeia Córrego do Meio, situada em reserva indígena na região central do Mato Grosso do Sul, basicamente agrícola. As características do sono noturno foram avaliadas por meio de questionário padronizado. Como resultado, verificamos o sono noturno relatado foi mais longo, o início do sono foi mais cedo e o despertar pela manhã também mais cedo, do que os índices descritos em populações urbanas. A média do tempo na cama foi $8,5 \mathrm{~h}$ ou mais em todos os grupos etários. A prevalência de insônia (no período de 7 dias) foi $4,6 \%$, ao passo que a prevalência do uso de hipnótico (no período de 7 dias) foi 1,5\%, ambos acentuadamente menores que os descritos em populações urbanas. Tais achados ressaltam a necessidade de se considerar as infuências étnicas ao avaliar caracteríticas e distúrbios do sono.

PALAVRAS-CHAVE: sono, hábito de dormir, insônia, distúrbio do sono, hipnótico, nativo, índio, Terena, Mato Grosso do Sul, étnico.

Social-economic and cultural factors play a relevant role determining diurnal ${ }^{1}$ and nocturnal sleep habits, including sleep duration, regular sleep onset time and morning wake up time. Several sleep disorders and treatments are also influenced by these factors, including the insomnias (disorders of initiating and maintaining sleep), and the use of hypnotic.

CDS-Centro de Distúrbios do Sono®, São Paulo, SP: *Diretor do CDS, Médico-Assistente da Divisão de Clínica Neurológica do Hospital das Clínicas da Faculdade de Medicina da Universidade de São Paulo; **Professor de Psicopatologia, Universidade Católica Dom Bosco (UCDB), Campo Grande, MS; ***Estudante de Graduação, Curso de Psicologia, UCDB, Campo Grande, MS; ****Estagiário. Aceite: 19-janeiro-2000.

Dr. Rubens Reimão - Rua Glicíneas 128 - 04048-050 São Paulo SP - Brasil. 
Table 1. Distribution of Terena adults evaluated, according to age and sex in Córrego do Meio village.

\begin{tabular}{cccc}
\hline $\begin{array}{c}\text { Age } \\
\text { (years) }\end{array}$ & M & F & Total \\
\hline $18-19$ & 3 & 3 & 6 \\
$20-29$ & 9 & 7 & 16 \\
$30-39$ & 5 & 11 & 16 \\
$40-49$ & 7 & 8 & 15 \\
$50-59$ & 3 & 2 & 5 \\
$60-69$ & 3 & 3 & 6 \\
$70-79$ & 1 & & 1 \\
Total & 31 & 33 & 64 \\
\hline
\end{tabular}

were conducted from house to house, encompassing all homes in this age range.

Sixty four Native Terena adults with ages (Table 1) ranging from 18 to 75 years (mean age 37.0 years) were evaluated ( $31 \mathrm{M} ; 33 \mathrm{~F}$ ). Mean age of males was 36.8 years, ranging from 18 to 75 years. Mean age of females was 37.2 years, ranging from 18 to 66 years. Sleep characteristics were investigated through interviews during the summer of January 1999. Interviews were conducted personally by the authors. Three male adults were not included because they worked out of the Indian Reservation, on an irregular sleep-wake schedule.

Ten yes/no multiple choice questions were employed focusing primarily on nocturnal sleep habits, the presence of insomnia and the use of medications to induce sleep with the questionnaire standardized by SBD Giglio $^{8}$. This is part of a larger sleep questionnaire data set that will be presented elsewhere.

\section{RESULTS}

The reported total time in bed (TTB) was mean of $8.5 \mathrm{~h}$ or more in every age bracket during weekdays (Fig 1) and week ends (Fig 2). There were no clear tendencies between gender or age groups. Even in the 60-69 year group the mean TTB was remarkably long of $10.3 \mathrm{~h}$ for $\mathrm{M}$ and $9.5 \mathrm{~h}$ for F.

Table 2. Sleep onset time and wake up time in Terena adults in Córrego do Meio village, according to age and sex.

\begin{tabular}{|c|c|c|c|c|c|c|}
\hline \multirow[t]{2}{*}{$\begin{array}{c}\text { Age } \\
\text { (years) }\end{array}$} & \multicolumn{3}{|c|}{$\begin{array}{l}\text { Sleep onset time } \\
\quad(\text { mean } \mathrm{h})\end{array}$} & \multicolumn{3}{|c|}{$\begin{array}{l}\text { Wake up time } \\
\quad(\text { mean } \mathrm{h})\end{array}$} \\
\hline & M & $\mathrm{F}$ & Total & $\mathrm{M}$ & $\mathrm{F}$ & Total \\
\hline $18-19$ & 17.0 & 21.3 & 19.1 & 7.2 & 6.3 & 6.7 \\
\hline $20-29$ & 21.4 & 20.7 & 21.0 & 6.2 & 6.5 & 6.3 \\
\hline $30-39$ & 22.4 & 21.0 & 21.7 & 5.8 & 6.2 & 6.0 \\
\hline $40-49$ & 20.1 & 21.5 & 20.8 & 7.4 & 5.7 & 6.5 \\
\hline $50-59$ & 21.0 & 20.0 & 20.5 & 4.5 & 6.0 & 5.2 \\
\hline $60-69$ & 19.0 & 19.5 & 19.2 & 5.3 & 5.0 & 5.1 \\
\hline $70-79$ & 19.5 & & 19.5 & 5.5 & & 5.5 \\
\hline
\end{tabular}




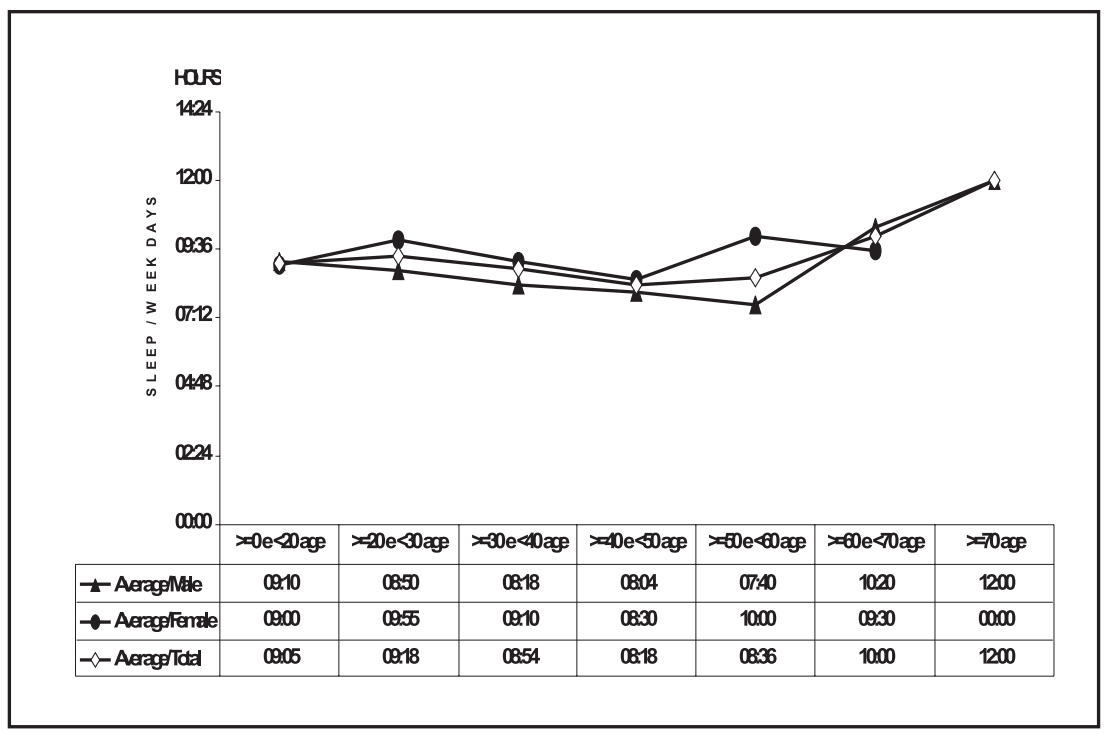

Fig 1. Week days reported nocturnal sleep duration in Terena adults in Córrego do Meio village, according to age and sex.

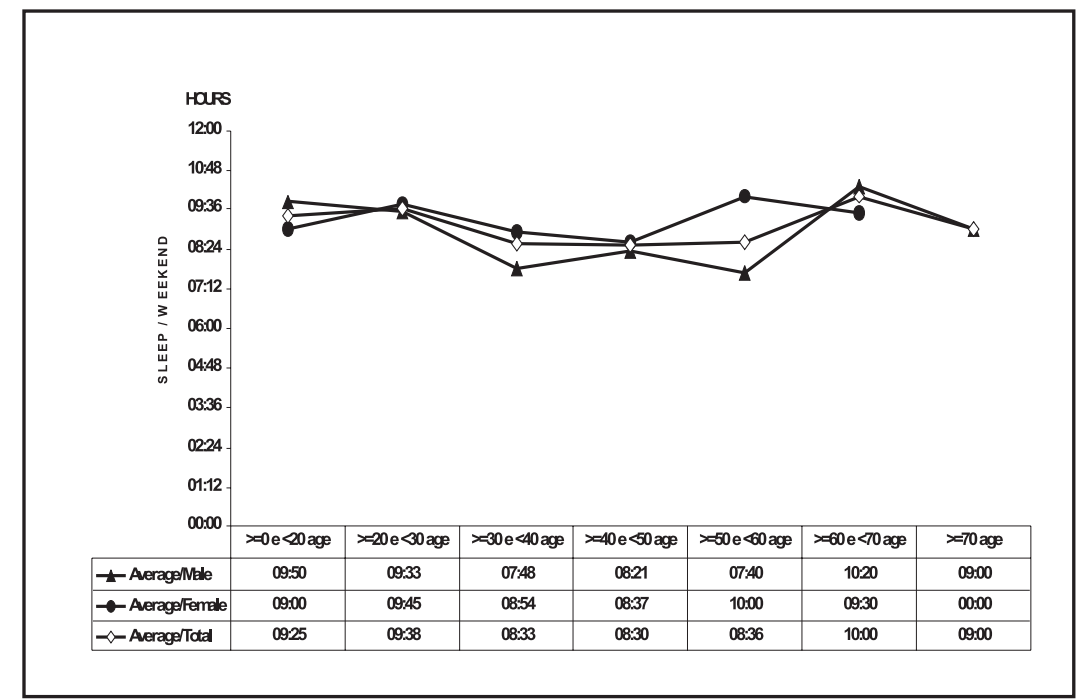

Fig 2. Weekends reported nocturnal sleep duration in Terena adults in Córrego do Meio village, according to age and sex.

The mean nocturnal sleep onset time was $20.8 \mathrm{~h}$ in males, and $17.7 \mathrm{~h}$ in females (Table 2). There was a mild tendency to sleep earlier in the 20 to 60 year olds, as the 20 year old group had a mean nocturnal sleep onset time of $21.0 \mathrm{~h}$ and the 60 year old group a mean of $19.2 \mathrm{~h}$. The eldest group (>70 years) was composed of only one individual precluding conclusions.

The mean morning wake up time was $5.7 \mathrm{~h}$ in males and $5.1 \mathrm{~h}$ in females. There was a slight trend to wake up earlier in the 20 to 60 year old group, as the 20 year old group had a mean morning wake up time of $6.3 \mathrm{~h}$ and the 60 year old group a mean of $5.1 \mathrm{~h}$. 
In the entire sample of 64 adults, only 3 referred present insomnia, so that seven-day prevalence rate of insomnia was $4.6 \%$. All these 3 cases were females, ages 21, 22 and 44; all of them described difficulty in initiating and maintaining sleep as well as waking up earlier than desired. Only one of them (44 years old) had ever reported the insomnia to a health care provider, and regularly takes a hypnotic; the two others had never used hypnotic, including Folk Medicine sleep inducing substances and alcohol.

In the entire sample of 64 adults, only one subject used hypnotic, so that seven-day prevalence rate of hypnotic use was $1.5 \%$. This was a 44 year old woman that took diazepam regularly.

\section{DISCUSSION}

The Terena population evaluated presented TTB longer than urban populations. In São Paulo city the mean TTB evaluation rate was of $7.7 \mathrm{~h}$ on weekdays $(7.5 \mathrm{~h} \mathrm{M} ; 7.8 \mathrm{~h} \mathrm{~F})^{8}$.

The progressive reduction of total sleep time with age has been described in early urban population studies ${ }^{9,10}$. However, more recent population studies focusing on healthy aged people (60-75 years old), also known as successful aging, suggest that the reduction is not seen or is mild ${ }^{11-14}$. It is supposed that the marked reduction present in the early studies could be due to concomitant diseases present in the general elderly population, and less in the healthy aged group. In the Terena population studied, there was a mild decrease in sleep duration from 20 to 60 year olds, this suggested that in a situation of very low time pressure, the sleep time reduction is mild.

In an urban population, Carrier et al. ${ }^{15}$ evaluated normal individuals 20 to 50 years old and observed a progressive reduction in the reported total sleep time, total time in bed, as well as sleep onset time progressively earlier as well as the early morning awakening. In this normal group, the mean TTB was $460.6 \mathrm{~min}$; the mean sleep onset time was $23.4 \mathrm{~h}$; the mean morning wake up time was $7.1 \mathrm{~h}$. In a population study with São Paulo city population, the mean sleep onset time was 23.6 $\mathrm{h}$ in A and B social-economic classes, while it was $22.6 \mathrm{~h}$ in the $\mathrm{C}$ and $\mathrm{D}$ ones ${ }^{8}$.

The sample of the Terena group here described confirm the longer TTB, earlier sleep onset time and earlier sleep wake up time compared to these urban populations, and one may propose that these habits are linked to basic agricultural activities, and minor influence of electricity, TV and radio. The time pressure reducing TTB is a fundamental trait in stressful urban industrial populations but not in the Terena culture. Several other factors also influence this pattern in Terena nocturnal sleep: A) the agricultural chores are also characterized by group participation and the Terena sleep pattern in which numerous persons sleep in the same room may facilitate the relatively homogeneous sleep schedule in this population; B) More than $90 \%$ of the Terena bedrooms are described as silent and comfortable for sleeping ${ }^{3,5}$; C) Weekends and week days have little difference in the agricultural chores in the Terena culture.

The seven-day prevalence rate of insomnia in the Terena was $4.6 \%$. which was remarkably lower than that reported in urban populations. In São Paulo city urban population, the seven-day prevalence rate was over $50 \%$ of the population ${ }^{8}$; in this population, insomnia was more prevalent in females and in those 30 years old or over. In a recent cross-sectional sample of the French population, the prevalence rate of insomnia was $48 \%$, and also more common in females ${ }^{16}$.Utilizing the same method of seven-day prevalence, the large Upper Bavarian Field Study adult population found that the prevalence rate was $28.5 \%{ }^{17}$, and confirmed the higher prevalence in females. Using the twoweek paradigm the insomnia prevalence rate was $34.9 \%$ in Brazilian university students ${ }^{18}$.

In a large representative sample of adults in the USA, Ancoli-Israel and Roth ${ }^{19}$ determined the prevalence of occasional insomnia in one fourth of the adult population; the prevalence of insomnia occuring regularly every night was found in $9 \%$. In this sample, insomniacs rarely visited a physician to discuss their problem; and four out of ten insomniacs self-medicated with either over-the counter medications or with alcohol. 
Among older persons, the prevalence of insomnia was determined as $23.4 \%{ }^{20}$. Foley et al. ${ }^{21}$ found that insomnia was more prevalent in older Afro-American women (19\%) compared in AfroAmerican men (12\%) and compared to Caucasian men and women (both 14\%). In this population ${ }^{21}$ they determined that women tend to maintain chronic insomnia longer than men.

In regard to health care, among adults that seek health sevices, 69\% reported occasional insomnia in San Diego, and 50\% in Honolulu; $19 \%$ mentioned chronic insomnia ${ }^{22}$.

Among individuals enrolled in a healthcare system in the USA ${ }^{23}$, one third reported insomnia with daytime dysfunction. In an evaluation of the São Paulo urban population, 9.8\% stated that they had previously looked for medical services reporting insomnia ${ }^{8}$.

Despite the fact that the prevalence of insomnia in this Terena group was remarkably lower than in urban population, it was predominant in middle-aged females, as in the urban populations. Several publications suggest that the predominance of insomnia in middle-aged females may be due to the fact that several mood and anxiety disorders start between 20 and 49 years of age. Major depression, bipolar depression, dysthymia, and generalized anxiety are predominant in females ${ }^{24-31}$. Stressful life situations, sub-optimal working conditions and inadequate sleep hygiene are relevant for maintaining insomnia ${ }^{32}$. Our present report did not aim to reach individual diagnosis, but this may be part of a future study.

The seven-day prevalence of hypnotic use observed in this Terena population was remarkably less than the described in recent urban population studies: A) A large cross-sectional sample of the French adult population ${ }^{16}$ showed that $2 \%$ to $10 \%$ of the population take hypnotic drugs; $8 \%$ take hypnotic regularly or for more than 6 months; $6.1 \%$ take them for more than 6 months and frequently or every night; $4.4 \%$ take hypnotic regularly for more than 5 years. B) In Germany ${ }^{17}$, the seven-day prevalence rate of hypnotic or other psychotropic drugs for insomnia in the general population was 9.5\%. Among those who referred insomnia, the seven-day prevalence of hypnotic use was $33.7 \%$. C) In the São Paulo urban population, the seven-day prevalence of hypnotic use was $25.9 \%{ }^{8}$. The hypnotic consumption by women was twice that of male consumption. In this urban sample ${ }^{8}$, the most reported drug was diazepam.

The remarkably reduced use of hypnotic by the Terena compared to urban populations may be due to the following factors. First, we would propose as the main factor the low prevalence of insomnia in this population, determined in the present report. Second, of less importance, one must mention the low availability of the hypnotic drugs. The Indian Reservation is distant from town and from medical resources reducing the availability of hypnotic drugs. The lack of reported regular use of Folk Medicine sleep inducing substances, and the lack of drive to look for treatment for insomnia in the cases described support the possibility that these women did not know that treatment was available, that insomnia was treatable, or did not wish it treated. This complex concept of insomnia and its treatment must be taken into account in the framework of the Terena culture.

\section{CONCLUSION}

The present report showed that nocturnal sleep in Terena adults was characterized by longer TTB, earlier sleep onset time, and earlier morning wake-up time than that described in urban populations. The prevalence of insomnia and the prevalence of hypnotic use were remarkably less than described in urban populations. Agricultural society, with much less time pressure than urban populations, more adequate sleep environment and habits may be factors favoring it. These findings point out the need to consider social-economic and ethnic factors in order to understand sleep and its disorders.

Acknowledgement - We are thankful to brother Alfredo Sganzela, and brother Sérgio Pedro Gonzatti of the Saint Francis of Assis Cultural Center, Sidrolândia, MS, for thoughtful teachings and logistic support of our staff. Prof. Ieda Marques de Carvalho, Coordinator of the Terena Program of the Center for Study of Native Brazilian Indian Populations (NEPPI), UCDB, for constant stimulus and support. To the Terena people, for friendship and hospitality. 


\section{REFERENCES}

1. Reimão R, Souza JC, Gaudioso CEV, et al.. Siestas among Brazilian native Terena adults: a study of daytime napping. Arq Neuropsiquiatr 2000;58:

2. Reimão R, Souza JCRP. Brazilian Folk Medicine for the treatment of insomnia: the use of medicinal plants as hypnotic in Campo Grande, State of Mato Grosso do Sul. Rev Bras Neurol Psiquiatr 1998;2:107-110.

3. Reimão R, Souza JCRP, Almirão RI, Medeiros MM. Sleep characteristics in the first two years of life in Native Terena children. Rev Bras Neurol 1998;34:159-162.

4. Reimão R, Souza JCRP, Gaudioso CEV. Sleep habits in Native Brazilian Bororo children. Arq Neuropsiquiatr 1999;57:14-17.

5. Reimão R, Souza JCRP, Medeiros MM, Almirão RI. Sleep habits in Native Brazilian Terena children in the State of Mato Grosso do Sul, Brazil. Arq Neuropsiquiatr 1998;56:703-707.

6. Mangolin O. Povos indígenas no Mato Grosso do Sul: viveremos por mais 500 anos.Campo Grande: CIMI, 1993.

7. Ribeiro D. Cultura e línguas indígenas no Brasil. Educação e ciências sociais. série: Vol 6. Rio de Janeiro: Centro Brasileiro de Pesquisas Educacionais, 1957.

8. Giglio SBD. Estudo da ocorrência das queixas de insônia, de sonolência excessiva diurna e das relativas às parassônias na população adulta da cidade de São Paulo. São Paulo: Escola Paulista de Medicina, 1988.

9. Cirignotta F, Mondini S, Zuconi M, Lenzi PL, Lugaresi E. Insomnia: epidemiological study. Clin Neuropharmacol 1985;8:S49-S51.

10. Lugaresi E, Cirignotta F, Zucconi M, Mondini S, Lenzi PL, Coccagna G. Good and poorsleepers: and epidemiological survey of the San Marino population. In Guilleminault C, Lugaresi E (eds). Sleep/wake disorders: natural history, epidemiology and long term evolution. New York: Raven Press, 1983:1-12.

11. Bliwise DL. Sleep in normal and dementia. Sleep 1993;16:40-51.

12. Hoch CC, Dew MA, Reynolds CF 3 rd, et al.. A longitudinal study of laboratory and diary-based sleep measures in healthy "old old" and "young old" volunteers. Sleep 1994;17:489-496.

13. Kupfer DJ. A longitudinal study of laboratory and diary-based sleep measures in healthy "old old" and "young old" volunteers. Sleep 1994;17:489-496.

14. Park YM, Matsumoto K, Seo YJ, Shinkoda H, Park KP. Sleep in relation to age, sex and chronotype in Japanese workers. Percept Mot Skills 1998;87:199-215.

15. Carrier J, Monk TH, Buysse DJ, Kupfer DJ. Sleep and morning-eveningness in the "middle" years of life (20-59y). J Sleep Res 1997;6:230-237.

16. Quera-Salva MA, Orluc A, Goldenberg F, Guilleminault C. Insomnia and use of hypnotics: study of a French population. Sleep 1991;14:386-391.

17. Weyrer S, Dilling H. Prevalence and treatment of insomnia in the community: results from the Upper Bavarian Field Study. Sleep 1991;14:392-398.

18. Souza JCRP. Insônia e qualidade de vida em estudantes universitários. Campo Grande: Universidade Católica Dom Bosco, 1999.

19. Ancoli-Israel S, Roth T. Characteristics of insomnia in the United States: results of the 1991 National Sleep Foundation Survey. Sleep 1999;22(Suppl 2):S347-S353.

20. Roberts RE, Shema SJ, Kaplan GA. Prospective data on sleep complaints and associated risk factors in a older cohort. Psychosom Med 1999;61:188-196.

21. Foley DJ, Monjan AA, Izmilian G, Hays JC, Blazer DG. Incidence and remission of insomnia among elderly adults in a biracial cohort. Sleep 1999;22(Suppl 2):S373-S378.

22. Schochat T, Umphresi J, Israel LAG, Ancoli-Israel S. Insomnia in primary care patients. Sleep 1999;22(Suppl 2):S357-S365.

23. Hatoum HT, Kong SX, Kania CM, Wong JM, Mendelson WB. Insomnia, health-related Quality of Life and healthcare resource consumption: a study of managed-care organization enrolees. Pharmacoeconomics 1998;14:629-637.

24. Buysse DJ, Browman KE, Monk TH, Reynolds CF 3rd, Fasiczka AL, Kupfer DJ. Napping and 24-hour sleep-wake patterns in healthy elderly and young adults. J Am Geriatr Soc 1992;40:779-786.

25. Coren S. The prevalence of self-reported sleep disturbances in young adults. Int J Neurosci 1994;79:67-73.

26. Gillin JC. Are sleep disturbances risk factors for anxiety, depressive and addictive disorders? Arch Psychiatr Scand 1998;(Suppl 1):39-43.

27. Gislason T, Reynisdottir H, Kristbjarson H, Benediktskottir B. Sleep habits and sleep disturbances among the elderly epidemiological survey. J Intern Med 1993;234:31-39.

28. Jewett ME, Dijk DJ, Kronauer RE, Dinges DF. Dose-response relationship between sleep duration and human psychomotor vigilance and subjective alertness. Sleep 1999;22:171-179.

29. Kobayashi R, Kohsaka I, Fukuda $\mathrm{N}$ et al. . Gender differences in the sleep of middle-aged individuals. Psychiatr Clin Neurosci 1998;52:186-197.

30. Margolis N. Prevalence, costs and consequences of insomnia reference bibliography: 1993-1998. Sleep 1999;22(Suppl 2):S409-S412.

31. Middlekoop HA, Smilde-Doel DA, Neven AK, Kamphuisen H, Springer CP. Subjective sleep characteristics of 1,485 males and females aged 50-93: effects of sex and age, and factors related to self-evaluated quality of sleep. J Gerontol Biol Sci Med Sci 1996;51:108-115.

32. Rosmond R, Lapidus L, Bjorntorp P. A cross-sectional study of self-reported work conditions and psychiatric health in native Swedes and immigrants. Occup Med (Lond) 1998;48:309-314. 